\title{
Assessment of Methane Flux from Municipal Solid Waste (MSW) Landfill Areas of Delhi, India
}

\section{Manju Rawat, AL. Ramanathan}

School of Environmental Sciences, Jawaharlal Nehru University, New Delhi, India.

Email: mrawat@yahoo.com, alrjnu@gmail.com

Received March 21 ${ }^{\text {st }}$ 2011; April 27 ${ }^{\text {th }}$ 2011; May 18 ${ }^{\text {th }}, 2011$.

\begin{abstract}
Carbon dioxide, methane and nitrous oxide are the major Greenhouse Gases (GHG's), which emit from landfill areas and contribute significantly to global warming. Moreover, that the global warming potential of methane is 21 times higher than that of carbon dioxide and it has highest generation (60\%) than other gases. Therefore, there is immense concern for its abatement or utilization from landfill areas. Compared to the west, the composition of municipal solid waste (MSW) in developing countries has higher ( $40 \%$ - 60\%) organic waste. This would have potential to emit higher GHG's from per ton of MSW compared to developed world. Beside that landfills areas in India are not planned or engineered generally low lying open areas, where MSW is indiscriminate disposed. This leads to uncontrolled emission of trace gases, foul smell, bird menace, ground and surface water pollution etc. Due to scarcity of land in big cities, municipal authorities are using same landfill for nearly 10 - 20 years. Hence, the possibility of anaerobic emission of GHG's further increases. In the present paper we had quantified the methane emission from three MSW landfill areas of Delhi i.e., Gazipur, Bhalswa and Okhla. The results showed that the range of methane emission various in winter from 12.94 to 58.41 and in Summer from $82.69-293 \mathrm{mg} / \mathrm{m}^{2} / \mathrm{h}$ in these landfill areas. The paper has also reviewed the literature on methane emission from India and the status of landfill areas in India.
\end{abstract}

Keywords: Landfill, Municipal Solid Waste, GHG Emission, India

\section{Introduction}

Due to fast economic growth in developing countries, there is tremendous increase in Municipal Solid Waste (MSW) generation in the last few decades. The MSW generation in India has increased from 6 million tons/ year in 1947 to 48 million tons/year in 1997, with per capita increase of $1 \%-1.33 \%$ per year [1]. According to СPCB [2] and IIR reports [3], the annual MSW generation in India ranges between $40-55$ million tons/year and this figure could be 270 million tons in 2047 (Figure 1). The cumulative land requirement for MSW disposal was $10 \mathrm{Km}^{2}$ in 1997 and estimated to be $75 \mathrm{Km}^{2}$ by 2007 (assuming $80 \%$ collection) [4] and would be $1400 \mathrm{Km}^{2}$ by 2047 [5]. Figure 2 is showing the world scenario of MSW disposal.

In India, the municipalities need to follow "Municipal Solid Waste (Management and Handling) Rules 2000", under the Environmental Protection Act (EPA) 1986, according to these rules it is mandatory to use sound and sustainable practices for management of MSW [6]. These rules have been divided into four Schedules, I-IV. The
Schedule I has the Implementation schedule for setting up landfill areas, Schedule II is about the improved techniques for the management of MSW, Schedule III is about specification for the MSW landfill sites- layering, capturing of GHG's, collection of leachates etc., and Schedule IV is about the MSW compost standards,

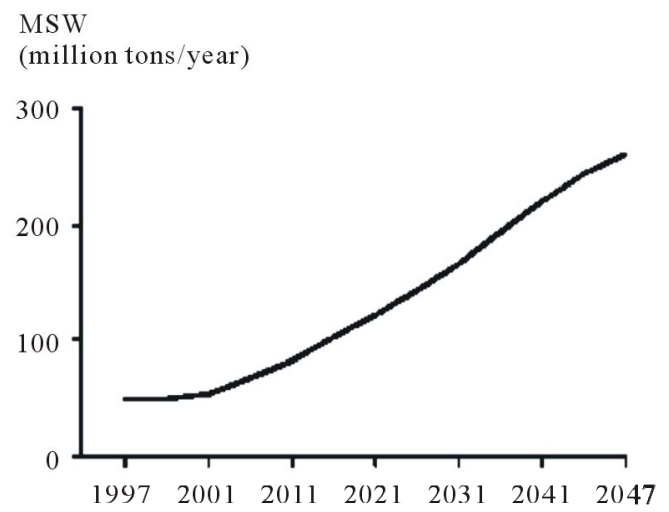

Figure 1. Trend of MSW generation in India. Source: Singhal and Pandey [5]. 


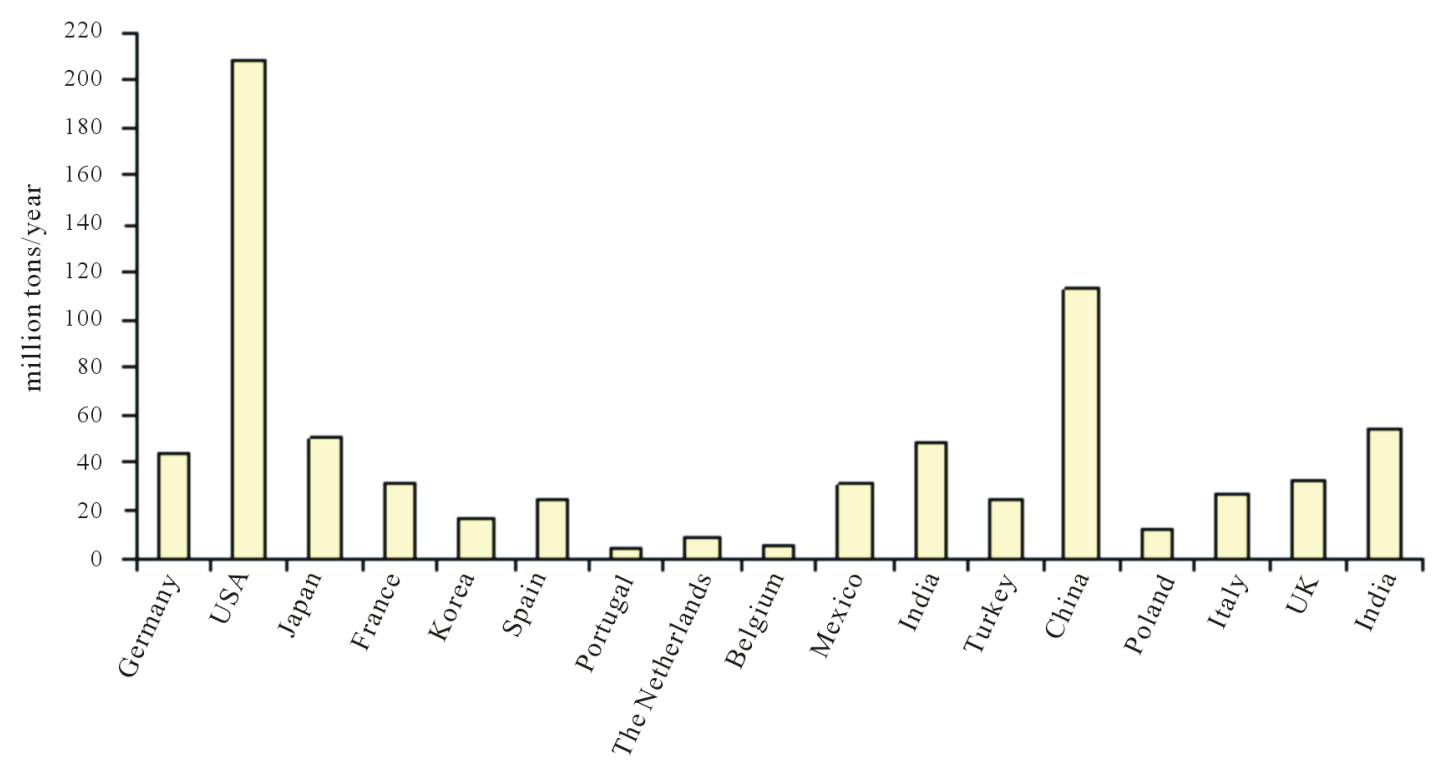

Figure 2. The World scenario of MSW generation (million tons/year). Source: Wang and Nie [7], World Bank [8].

treated leachates and Incineration of MSW. But still compliance to these rules is not evident.

Globally too, landfill has been used for many years as a most economic method of refuse disposal. On the global scale approximately 6530 billion tones of waste is land filled $[9,10]$. The organic component in landfill municipal refuse results in GHG emission via microbial decomposition by anaerobic condition. The average composition of landfill gases is $50 \%$ methane and $45 \%$ carbon dioxide, $5 \%$ Nitrogen gas, $<1 \%$ hydrogen sulphide and 2700 ppmv non-methane organic compounds (NMOCs) such as trichloroethylene, benzene, and vinyl chloride [11,12].

Due to an increase in population and subsequently increase in waste generation, landfills could become a major source of atmospheric methane [13]. Methane, at its current atmospheric concentration of $1.7 \mathrm{ppmv}$, accounts for about $15 \%$ of the anthropogenic greenhouse effect and concentration is on the increase [14,15]. Global methane emissions from landfill are estimated to increase app. 30 million tons every year. Most of this landfill methane currently comes from developed countries, where the levels of waste generation per capita are high. It is reported that solid waste disposal is the landfill is the main emitter of methane in the atmosphere around $80 \%$ [16].

Generally, 50\% of carbon emissions in the landfills are transformed into methane [17]. It has been reported that $13 \%$ of landfill emission or $36.7 \mathrm{Tg}$ /year of methane is emitted from municipal solid waste landfills in the World [12]. Other reports said that the global projection of methane flux from landfill areas would be 63 - 93 $\mathrm{Tg} /$ year by 2050 [18], which will be due to population growth and subsequently increase in waste dumping in landfills. Some author's had tried to evaluate the accuracy of methane inventories in India [19].

In India, the MSW management (collection, storage, transportation, processing and disposal) has been done by municipal authorities in cities and by local bodies in rural areas. The MSW management scenario is more severe in Indian metro cities, where with large population growth, MSW generation rate is increasing but waste management strategies are not in pace with it. Like any other country, in India too landfill remains the most popular method of disposal of MSW as landfill is more economic way of disposal of waste. The present scenario is such that landfills in metro cities have been used for almost 15-20 years and there is big mountain of MSW in it (Table 1). Scarcity of land in the cities and awareness among the citizens (NIMBY) made it difficult to find new landfill sites. At present, Environmental Impact Assessment (EIA) has become compulsory to construct any waste processing and landfill area in India. Therefore, the planned landfill sites, methane gas utilization and reusing material has made compulsory in India. After 5 10 days from MSW management scenario might be better.

At present, the GHG emission from insecure landfills remains the big issue for MSW management in India. Landfill gas release represents physical (explosion), chemical (substances in ambient or indoor air or odor), and quality of life public health concerns for those who live near or work in landfill. Indiscriminate land filling leads to deterioration of water quality in neighborhood areas. This has adverse health impacts on people living nearby landfill and they are in the constant fear of explo- 
sion of accumulated methane gas. The methane gas utilization as an energy resource is not well studied and practice in India. Whereas, large number of studies are available in western countries on landfill gas utilization as renewable energy source. It has been reported that there are around 955 energy recovery landfills in the world and maximum are in United States, 325 nos. [12]. Approximately, 26 - 27 million tons/year of MSW in US have been utilized for converting waste to energy. Some other studies are on improvement in emission of GHG from landfills and its utilization in electricity generation [20-22].

The GHG emission from landfill areas in India has come into focus in last ten to twelve years and there is more number of studies on methane emission from landfill areas. In 1980 and 1990's, the GHG emission from Paddy field remained the main research area of study. The earliest studies reported on landfill improvement and
GHG's was by Shekdar et al. [23] and Bhide [24]. Bhide [24] had reported total methane flux from Indian cities as $0.33 \mathrm{Tg} /$ year. Recently, there are few studies reported on $\mathrm{CO}_{2}$ and $\mathrm{N}_{2} \mathrm{O}$ emission from landfills. Among them, there are some studies on field experiments and many others are theoretical estimation using various calculations methods. In the present study an attempt has been made to calculate the methane flux from three lanfill areas of Delhi i.e., Gazipur landfill area (GLA), Okhla Landfill area (OLA) and Bhalswa landfill area (BLA), which is one of the highly populated city if India (Table 2). This study has also reviewed the research work done on GHG emission from landfill areas in India.

\section{Mechanism of Formation of Methane Emission from Landfill Areas}

The various Landfill gases viz., carbon dioxide, methane and nitrous oxide are produced primarily produce by

Table 1. Status of landfill sites in some million plus cities of India.

\begin{tabular}{|c|c|c|c|c|c|c|c|}
\hline S. No & $\begin{array}{l}\text { Name of city } \\
\text { (No. of } \\
\text { landfill sites) }\end{array}$ & $\begin{array}{c}\text { Area of landfill } \\
\text { (ha) }\end{array}$ & $\begin{array}{l}\text { Life of landfill in } \\
\text { Years/New site } \\
\text { proposed }\end{array}$ & S. No. & $\begin{array}{c}\text { Name of } \\
\text { City (No. of landfill } \\
\text { sites) }\end{array}$ & $\begin{array}{l}\text { Area of } \\
\text { landfill } \\
\text { (ha) }\end{array}$ & $\begin{array}{c}\text { Life of landfill in } \\
\text { Years/New site } \\
\text { proposed }\end{array}$ \\
\hline 1 & Indore (1) & 59.50 & -/No & 22 & Itanagar (1) & - & -/No \\
\hline 2 & Bhopal (1) & - & -/No & 23 & Surat (1) & 200.00 & -/No \\
\hline 3 & Dhanbad (3) & - & -/No & 24 & Rajkot (2) & 1.20 & -/Yes \\
\hline 4 & Ranchi (1) & 15.00 & -/No & 25 & Pune (1) & - & -/No \\
\hline 5 & Bhubaneshwar (4) & - & -/Yes & 26 & Simla (1) & 0.60 & -/No \\
\hline 6 & Ahmedabad (1) & 84.00 & 30/Yes & 27 & Madurai (1) & 48.60 & 35/No \\
\hline 7 & Nashik (1) & 34.40 & 15/No & 28 & Jaipur (3) & 31.40 & -/No \\
\hline 8 & Bangalore (2) & 40.70 & $-/ \mathrm{No}$ & 29 & Kochi (1) & - & -/No \\
\hline 9 & Agartala (1) & 6.80 & 14/yes & 30 & Coimbato (2) & 292.00 & -/No \\
\hline 10 & Agra (1) & 1.50 & 30/No & 31 & Chandigarh (1) & 18.00 & -/No \\
\hline 11 & Allahabad (2) & - & -/No & 32 & Thiruvananthp uram (1) & 12.15 & -/No \\
\hline 12 & Faridabad (3) & 2.40 & -/No & 33 & Panjim (1) & 1.20 & 30/No \\
\hline 13 & Lucknow (1) & 1.40 & 3/Yes & 34 & Hyderabad (1) & 121.50 & -/No \\
\hline 14 & Meerut (2) & 14.20 & $-/ \mathrm{No}$ & 35 & Gangtok (1) & 2.80 & $-/ \mathrm{No}$ \\
\hline 15 & Visakhapattnam (1) & 40.50 & 25/No & 36 & Varanasi (1) & 2.00 & $-/$ Yes \\
\hline 16 & Dehradun (1) & 4.50 & -/Yes & 37 & Kanpur (1) & 27.00 & -/No \\
\hline 17 & Guwahati (1) & 13.20 & -/No & 38 & Port Blair (1) & 0.20 & 6/Yes \\
\hline 18 & Amritsar (1) & - & -/Yes & 39 & Srinagar(1) & 30.40 & -/No \\
\hline 19 & Delhi (3) & 66.40 & -/No & 40 & Greater Mumbai (3) & 140.00 & -/No \\
\hline 20 & Kolkata (1) & 24.70 & 35/Yes & 41 & Jammu (1) & - & 10/Yes \\
\hline 21 & Chennai (2) & 465.50 & 24/17/No & 42 & Chennai (2) & 465.50 & 24/17/No \\
\hline
\end{tabular}

Source: CPCB-NEERI [25], -data not available. 
Table 2. Showing three landfill sites of Delhi with their present scenario.

\begin{tabular}{|c|c|c|c|c|c|}
\hline Name & Location & Area (hectares) & Start year & $\begin{array}{l}\text { Waste received } \\
\quad(\mathrm{Tpd})\end{array}$ & Zones supplying waste \\
\hline Bhalswa & North Delhi & 21.06 & 1993 & 2200 & Civil Lines, Karol Bagh, Rohini, Narela, Najafgarh and West \\
\hline Gazipur & East Delhi & 29.16 & 1984 & 2000 & $\begin{array}{l}\text { Shahdara (South), Shahdara (North), City, Sadar Paharganj, } \\
\text { and NDMC }\end{array}$ \\
\hline Okhla & South Delhi & 16.2 & 1994 & 1200 & Central, Najafgarh, South and Cantonment Board \\
\hline
\end{tabular}

bacterial decomposition of organic waste. Methane has 21 times more Global Warming Potential (GWP) then the carbon dioxide. Atmospheric methane concentration has more then doubled during the last 100 years and continues to rise. This has been estimated that more then $10 \%$ of global anthropogenic source of methane is from MSW landfills [26].

Methane: Methane is produced in large quantity in landfills, as a consequence of the degradation of organic matter under anaerobic conditions [27]. Landfills often accept waste over a 20 - 30 years period, so waste in a landfill may be undergoing several phases of decomposition. This means that older waste in one area might be in a different phase of decomposition than more recently buried waste in another area. It escapes from landfills either directly to the atmosphere or by diffusion through the cover soil. Methane in landfill area results from the metabolic activities of a small and highly specific bacterial group. The bacteria metabolise glucose, amino acids and fatty acids to organic acids (primarily acetic and propionic) and carbon dioxide, hydrogen gas, ammonia gas, nitrogen gas and water [11].

1. Complex organic matter------Soluble molecules

2. Acetogenesis

$$
\mathrm{C}_{6} \mathrm{H}_{12} \mathrm{O}_{6} \text {------- } \mathrm{C}_{2} \mathrm{H}_{5} \mathrm{OH}+\mathrm{CH}_{3} \mathrm{COOH}+2 \mathrm{CO}_{2}+2 \mathrm{H}_{2}
$$

\section{Methanogenesis}

$$
2 \mathrm{CH}_{3} \mathrm{COOH} \text {---------- } \mathrm{CH}_{4}+\mathrm{CO}_{2}
$$

4. This process also involves reduction of:

$$
\mathrm{CO}_{2}+8 \mathrm{H} \text {--------- } \mathrm{CH}_{4}+2 \mathrm{H}_{2} \mathrm{O}
$$

The process involves breakdown of acetic acid as:

$$
\mathrm{CH}_{3} \mathrm{COOH} \text {---------- } \mathrm{CH}_{4}+\mathrm{CO}_{2}
$$

This process also involves reduction of:

$$
\mathrm{CO}_{2}+8 \mathrm{H} \text {--------- } \mathrm{CH}_{4}+2 \mathrm{H}_{2} \mathrm{O}
$$

\section{Conditions Affect Landfill Gas Production}

The rate and volume of landfill gas produced at a specific site depends on the characteristics of the waste (e.g., composition and age of the refuse) and a number of environmental factors (e.g., the presence of oxygen in the landfill, moisture content, and temperature).

The waste composition-The more organic waste present in a landfill, the more landfill gases is produced by the bacteria decomposition [28]. The more chemicals disposed of in the landfill, the more likely NMOCs and other gases will be produced either through volatilization or chemical reactions [12].

The Age of refuse-Generally, more recently buried waste (i.e., waste buried less than 10 years) produces more landfill gas through bacterial decomposition, volatilization, and chemical reactions than does older waste (buried more than 10 years). Peak gas production usually occurs from 5 to 7 years after the waste is buried. Kumar et al. [29], noticed the highest methane emission using modified triangular method (MTM) in 5 - 6 years old landfill.

$\mathrm{pH}$ of waste-At $\mathrm{pH}$ 6.8-7.4 and at higher moisture contents, the methane emission in landfill areas reported to be high [28]. Ladapo and Bariaz [30], had reported pH near to neutral as good for methanogenesis as observed by them for landfill areas.

The Moisture content-The presence of moisture (unsaturated conditions) in a landfill increases gas production because it encourages bacterial decomposition. Moisture may also promote chemical reactions that produce gases [18,20,29].

The Temperature-As the landfill's temperature rises, bacterial activity increases, resulting in increased gas production [29]. Increased temperature may also increase rates of volatilization and chemical reactions. The increase in methane flux at day time when temperature is $30^{\circ} \mathrm{C}-40^{\circ} \mathrm{C}$, it is an optimum temperature and an important factor for the production of methane [18,24].

\section{Methane emission from Indian landfills}

The total methane flux from landfill areas of Indian cities was reported as $0.33 \mathrm{Tg} /$ year [24]. Whereas, most of the study done on landfills in India are on characterization, quantification and management practices of solid waste, not on emission of landfill gases and their utilization. Garg et al. [31] had mentioned in their study that $10 \%$ of methane emission is from waste sector of all. They had estimated that the total $\mathrm{CO}_{2}, \mathrm{CH}_{4}$ and $\mathrm{N}_{2} \mathrm{O}$ emission from India from all sectors was as 778.00, 18.00 and $0.30 \mathrm{Tg}$ in 1995 and in 1990 it was 592.5, 17.00 and 0.2 Tg re- 
spectively. They compounded the annual growth rate (CAGR) from India as 6.3, 1.2 and $3.3 \%$ for $\mathrm{CO}_{2}, \mathrm{CH}_{4}$ and $\mathrm{N}_{2} \mathrm{O}$ respectively. They further stated that MSW disposal by urban population generates $0.045 \mathrm{Kg}$ methane per kg waste [32]. According to Garg et al. [31], the methane emission in 1990 was $4.9 \mathrm{~kg} /$ capita/year and increased to $5.7 \mathrm{~kg} / \mathrm{capita} /$ year in 1995 . The total methane emission from Indian landfill calculated by them was $1.8 \mathrm{Tg} /$ year in 1995.

Bhattacharya and Mitra [33] reported methane emission from MSW in India was $0.56 \mathrm{Tg}$ in 1990 and 0.93 $\mathrm{Tg}$ in 2000. Mor et al. [34] had estimated the methane emission from Gazipur landfill area of Delhi using first order decay model as $15.3 \mathrm{Gg}$ /year. They have further estimated the methane generation from Indian landfills as 1.25 - $1.68 \mathrm{Tg} /$ year. Similarly, Kumar et al. [29] estimated the methane emission from Okhla landfill area of Delhi by using modified triangular method (MTM) as $14.0 \mathrm{Gg}$ for $2000-2001$ and by field experiments as 1.8 Gg per year.

The GHG emission calculated from the waste by Sharma et al. [35] as $1003 \mathrm{Gg}$ of methane, $7 \mathrm{Gg}$ of $\mathrm{N}_{2} \mathrm{O}$ and total $\mathrm{CO}_{2}$ equivalent emission as $23,233 \mathrm{Gg}$ per year from India in 1994. They had also done preliminary estimation as 14,133 and $28,637 \mathrm{Gg} \mathrm{CO}_{2}$ equivalent emission in 1990 and 2000 respectively. The CAGR calculated by them from waste as 7.3\% (1994-2000).

The methane emission by open dumping and improper land filling of MSW contribute to 3\% - 19\% of the anthropogenic sources in the world [36]. Talyan et al. [36], had used systemic dynamics modeling approach for projected the methane emission would be $254 \mathrm{Gg} /$ year by 2025 from MSW of Delhi. They further anticipated that future methane emission can unlikely to increase due to intervention of policy proposed like energy recovery from waste treatment and disposal. Gupta et al. [37], had proposed the setting up of Bioreactor landfill for MSW disposal in Delhi. This approach could reduce the greenhouse effect from landfill gases. The other study has estimated the methane generation in India at present around $10 \mathrm{Tg} /$ year and by 2047 would be $39 \mathrm{Tg}$ /year (Figure 3).

This is clear from the research work done in India on GHG from landfill areas is that the most of the studies are concentrated on bigger cities or metro-cities. The Table 1 shows that there are 59, million plus cities in India and they all have 1-2 landfill areas. There is need to estimate the GHG emission in smaller cities too, which are developing in very fast speed. The methane emission estimated in most of the studies ranges from $0.33-1.80$ Tg per year, nitrous oxide as $7 \mathrm{Gg}$ per year [35] and total carbon dioxide equivalent as $38.2 \mathrm{Tg}$ per year from MSW of India [31]. The energy or electricity generation

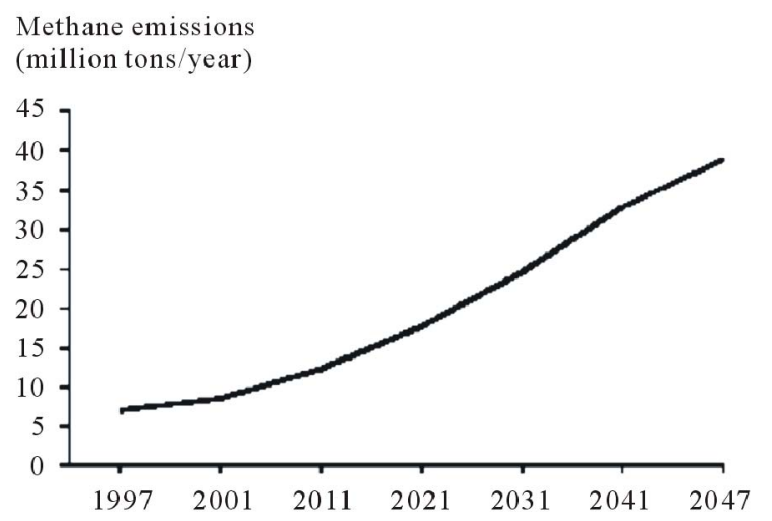

Figure 3. Trend of methane generation in Indian. Source: Singhal and Pandey [6].

option has been not well utilized from landfill areas. Beside that efforts have not been put to gain, Carbon Emission Reduction (CER) points under CDM benefits, from sustainable waste management practices in India. This could be a way to generate finances for sustainable management of MSW in India.

\section{Materials and Method}

Methane samples were collected from three landfill areas of Delhi, twice in December 2008 and in June 2009. These samples were analysed using Flame Ionization Detector (FID) of Gas Chromotograph.

\subsection{Collection of Methane}

Methane standard of 108 ppvm, EDT, London, UK was used for the analysis of methane in collected samples. Methane gas was collected using 'Close Chamber' technique. The gas was collected, stored and transported in a number of vials and sealed immediately after collection. Triplicates from every sampling site were taken. The Perspex chamber inserted had a base of 12 " $\times 12$ " $\times 3$ " and chamber of $12^{\prime \prime} \times 12^{\prime \prime} \times 18^{\prime \prime}$ dimensions. The Perspex chamber was embedded in the landfills a few hours in advance to ensure that the ambient soil environment was maintained. The gas collected in the chamber was transferred to the sampling vials by displacement of water. The sample was collected at regular intervals of one hour started from the time the chamber was placed during the course of the day. The landfills temperature at 5 $\mathrm{cm}$ depth and atmospheric temperature were also continuously monitored. The gas samples were analysed using Porapak Q column by FID of Gas Chromatograph (GC). Temperature in soil and atmosphere was measured by pre-calibrated thermometer.

\subsection{Quantification of Methane}

The methane flux is measured using GC- FID, and calculated by the formula given in $[27,38]$. 


\section{Results and Discussion}

The result for the samples analysed for methane is given in Table 3 and Figure 4.

The winter samples had showed lower concentration of methane emission then the summer samples collected from three landfill areas of Delhi, India. This fact is well known that organic components in MSW decompose faster in summer the winter and optimum temperature for methane emission is $30^{\circ} \mathrm{C}-40^{\circ} \mathrm{C}$. The highest methane emission has been reported in GLA of Delhi (293 $\mathrm{mg} / \mathrm{m} 2 / \mathrm{h}$ ) in summer samples at $3 \mathrm{pm}$, when the atmospheric temperature was around $45^{\circ} \mathrm{C}$, followed by 264 $\mathrm{mg} / \mathrm{m} 2 / \mathrm{h}$ in summer samples of BLA and $260 \mathrm{mg} / \mathrm{m} 2 / \mathrm{h}$ in summer sample of OLA. The reason for higher methane release from GLA might be due to presence large quantity of slaughter house waste. Winter samples were collected from $11 \mathrm{pm}$ on words in day time. In winter's, the highest emission has been observed in OLA as $58 \mathrm{mg} / \mathrm{m}^{2} / \mathrm{h}$ at $3 \mathrm{pm}$ and the lowest in winter at Bhalswa landfill area as $13 \mathrm{mg} / \mathrm{m}^{2} / \mathrm{h}$ at $5 \mathrm{pm}$ in evening, when the atmospheric temperature was around $4^{\circ} \mathrm{C}-5^{\circ} \mathrm{C}$. The total duration for a day samples was 5 hours starting from, $10 \mathrm{am}$ to $5 \mathrm{pm}$ in a day time. Monitoring has been done twice in each summer season and winter season. The similar results were reported on landfill methane emission by different authors like Jha et al. [39], and Ankolar et al. [40]. They had estimated methane emission flux range as $1-433 \mathrm{mg} / \mathrm{m}^{2} / \mathrm{h}$ from two landfill areas of Chennai and $0.273-1.659 \mathrm{mg} / \mathrm{m}^{2} / \mathrm{sec}$ from Pune landfill areas in India, respectively. Quantity of methane emission reported world wide from MSW landfill areas is as, $0.54-320 \mathrm{mg} / \mathrm{m}^{2} / \mathrm{h}$ by Börjesson and Svensson [18], from landfill areas in Sweden and Chen et al. [41] quantified the methane emission from the closed landfill site of $8.8-163 \mathrm{mg} / \mathrm{m}^{2} / \mathrm{h}$ for landfill area of Taiwan. Similar, findings were reported by Bogner and Matthews [42] for landfill methane emission.
The total major area covered by the selected three landfill areas is given in Table 1. Taking methane emission average of both seasons the total methane flux calculated for Gazipur, Bhalswa and Okhla landfill areas were calculated as $0.24,0.16$ and $0.14 \mathrm{Gg}$ /year respecttively [38]. Rawat et al. [27], had reported the methane emission from six landfill areas i.e., Perungudi (Chennai); Dapha (Kolkata); Okhla (Delhi); KCDC (Bangalore); Pirana (Ahmedabad) and Doran landfill area (Dehradun) of India as $0.21 \mathrm{Tg} /$ year. As stated earlier that similar results were estimated by Bhattacharya and Mitra [33], reported methane emission from MSW in India was 0.56 Tg (1990) and $0.93 \mathrm{Tg}$ (2000). Similarly, Mor et al. [34], estimated the methane emission from Gazipur landfill area of Delhi using first order decay model as 15.3 $\mathrm{Gg} /$ year and further estimation for all Indian landfills as 1.25 - $1.68 \mathrm{Tg} /$ year.

Houghton et al. [43], suggested that the soils are considered as a significant sink for atmospheric methane. They also reported that landfill covered with smaller soil particles are important for attenuating fluxes of methane and transforming methane to carbon dioxide, by means of methane oxidation.

\section{Conclusions}

The total methane flux calculated for three landfill areas of Delhi (Gazipur, Bhalswa and Okhla) is as 0.54 $\mathrm{Gg} /$ year, which is relatively in higher side as compare to the total methane emission estimated from MSW landfill sites in India i.e., from 0.30 - $1.8 \mathrm{Tg}$ per year. This could be that Delhi's MSW generation is higher then the other cities and most of the waste goes without segregation to landfills. With the growing population, the generation of solid waste has increased many folds. There is need to initiate mitigation steps for decreasing GHG emission from landfill areas. It can be done in first place by reducing the dumping of organic materials in landfills,

Table 3. Showing methane emission from landfill areas in $\mathrm{mg} / \mathrm{m}^{2} / \mathrm{h}$.

\begin{tabular}{|c|c|c|c|c|c|c|c|c|}
\hline \multicolumn{2}{|c|}{ Okhla landfill Area } & \multirow[b]{2}{*}{ Summer } & \multicolumn{3}{|c|}{ Gazipur landfill Area } & \multicolumn{3}{|c|}{ Bhalsawa landfill Area } \\
\hline Time (hour) & Winter & & Time (hour) & Winter & Summer & Time (hour) & Winter & Summer \\
\hline 11 & 0 & 0 & 11 & 0 & 0 & 11 & 0 & 0 \\
\hline 12 & 20.585 & 163.675 & 12 & 32.29 & 114.785 & 12 & 17.91 & 109.825 \\
\hline 13 & 28.7623 & 161.55 & 13 & 29.715 & 162.255 & 13 & 28.315 & 126.83 \\
\hline 14 & 37.71 & 145.96 & 14 & 45.52 & 123.29 & 14 & 50.89 & 168.635 \\
\hline 15 & 58.41 & 260.035 & 15 & 39.68 & 293.335 & 15 & 37.265 & 263.58 \\
\hline 16 & 43.965 & 134.625 & 16 & 23.2 & 180.68 & 16 & 19.685 & 138.165 \\
\hline 17 & 30.26 & 140.29 & 17 & 14.79 & 152.31 & 17 & 12.94 & 82.685 \\
\hline
\end{tabular}




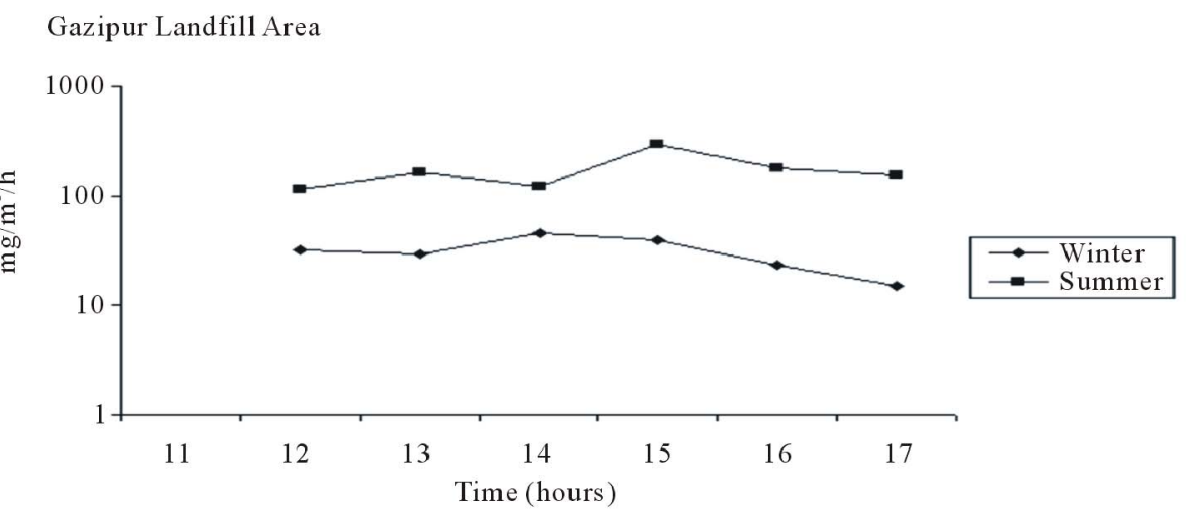

Bhalaswa Landfill Area

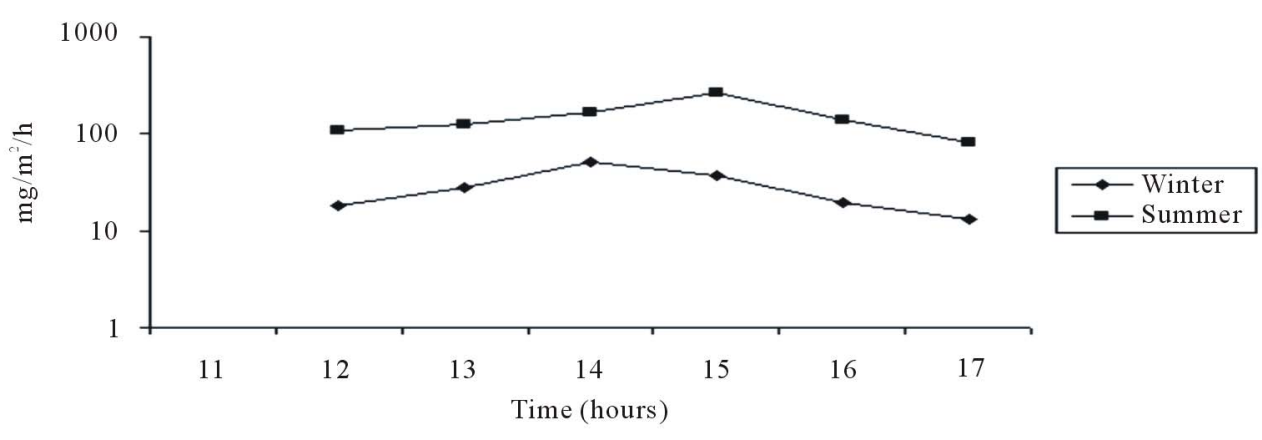

Okhla Landfill Area

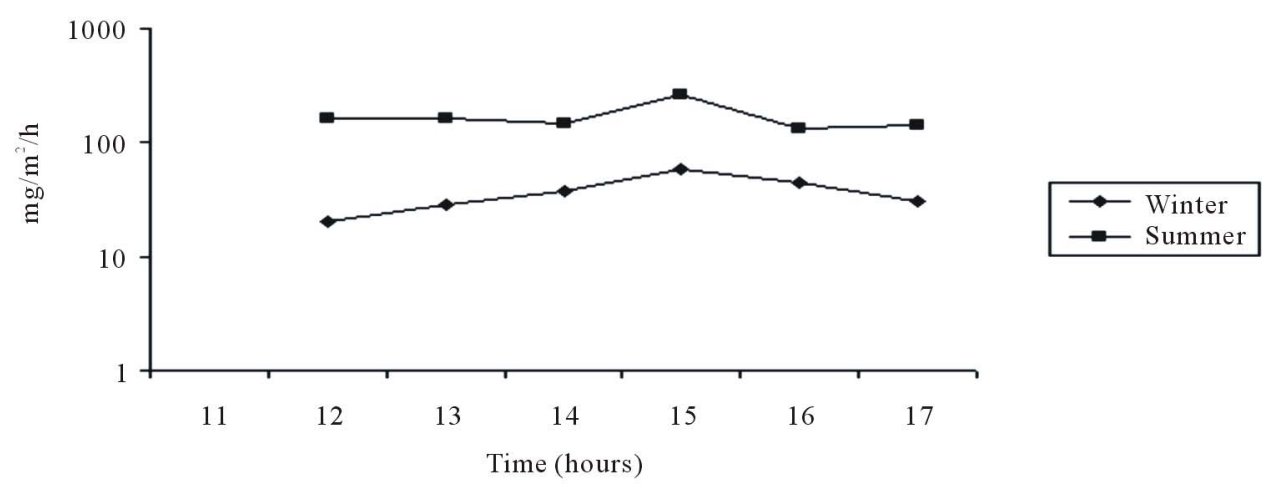

Figure 4. Showing methane emission (winter and summer) from landfill areas of Delhi.

which is possible by segregating organic component from solid waste, which can be effectively used for making compost. Secondly, there is need to construct a planned landfill site, from where GHG from landfill can be trapped and used as green energy source, as practiced in most of the developed countries.

\section{Acknowledgements}

Authors are thankful to the Department of Science and Technology (DST), Government of India for the financial support to carry out this research work.

\section{REFERENCES}

[1] K. J. Rao and M. V. Shantaram, "Soil and Water Pollution Due to Open Landfills,” Proceedings of sustainable landfill management workshop, 3-5 December 2003, Chennai, pp. 27-38.

[2] CPCB (Central Pollution Control Board), Management of Municipal Solid Wastes, 2005. Details available at $<$ http://cpcb.nic.in/pcpdiv_plan4.htm>, last accessed on 5 July 2006.

[3] IIR (India Infrastructure Report), Urban Infrastructure New Delhi, Oxford University Press, Oxford, 2006. 
[4] TERI (The Energy Research Institute), DISHA (Directions, Innovations, and Strategies for Harnessing Action) TERI publication, Delhi, 2001, p. 368

[5] S. Singhal and S. Pandey, "Solid Waste Management of India, Status and Future Direction”, TERI Information monitor on Environment Sciences, Vol. 6, No. 1, 2001, pp. 1-4.

[6] MoEF Website, http://www.moef.nic.in (last access 12/03/2010).

[7] Y. N. H. Wang, "Municipal Solid Waste Characteristics and Management in China," Journal of the Air and Waste Management Association, Vol. 51, No. 2, 2001, pp. 250-263.

[8] World Bank, Waste Management in China: issues and recommendations [Urban Development Working Papers] Washington, DC: East Asia Infrastructure Department, World Bank. 2005.

[9] S. A. Thorneleo, "Methane Emission from Landfill and Open Dumped,” In: A. R. van Amsted, Ed., Proceeding of the International IPCC workshop, Amersfoort, The Netherlands, 1993, pp. 93-109.

[10] P. Boeckx and V. O. Cleemput, "Flux Estimates from Soil Methanogenesis and Methanotrophy: Landfills, Rice Paddies, Natural Wetlands and Aerobic Soils,” Environmental Monitoring and Assessment, Vol. 42, No. 1-2, 1996, pp. 189-207. doi:10.1007/BF00394050

[11] C. M. Lee, X. R. Lin, C. Y. Lan, C. L. L. Samuel and G. Y. S. Chan, "Evaluation of Leachate Recirculation on Nitrous Oxide Production in the Likang Landfill, China," Journal of Environmental Quality, Vol. 31, No. 5, 2002, pp. 1502-1508. doi:10.2134/jeq2002.1502

[12] J. T. Nickolas and P. A. Ulloa, "Methane Generation in Landfills”, Renewable Energy, Vol. 32, No. 7, 2007: pp. 1243- 1257. doi:10.1016/j.renene.2006.04.020

[13] G. J. J. Kreileman and A. E, Bouwman, "Computing Land Use Emission of Greenhouse Gases," Water, Air and Soil Pollution, Vol. 76, No. 1-2, 1994, pp. 231-258. doi:10.1007/BF00478341

[14] R. E. Dickinson and R. J. Cicerone, "Future Global Warming from Atmospheric Trace Gases”, Nature, Vol. 319, 1986, pp. 109-115. doi:10.1038/319109a0

[15] H. Rodhe, "A Comparison of the Contribution of Various Gases to the Greenhouse Effect," Science, Vol. 248, No. 4960, 1990, pp. 1217-1219. doi:10.1126/science.248.4960.1217

[16] B. R. Gurjar, J. A. V. Aardenne, J. Lelieveld and M. Mohan, "Emission Estimates and Trends (1990-2000) for Megacity Delhi and Implications," Atmospheric Environment, Vol. 38, No. 33, 2004, pp. 5663-5681. doi:10.1016/j.atmosenv.2004.05.057

[17] H. G. Bingemer and P. J. Crutzens, "The Production of Methane from Solid Waste,” Journal of Geophysics Resource, Vol. 92, No. D2, 1987, pp. 2181-2187. doi:10.1029/JD092iD02p02181

[18] G. Börjesson and HBo. Svensson, "Seasonal and Diurnal Methane Emissions from a Landfill and Their Regulation by Methane Oxidation," Waste Management and Research, Vol. 15, 1997, pp. 33-54.

[19] S. Subak, "On Evaluating Accuracy of National Methane Inventories,” Environmental Science and Policy, Vol. 2, No. 3, 1999, pp. 229-240. doi:10.1016/S1462-9011(99)00017-9

[20] H. Hettiarachchi, J. Meegoda and P. Hettiarachchi, "Effects of Gas and Moisture on Modeling of Bioreactor Landfill Settlement,” Waste Management, Vol. 29, No. 3, 2009, pp. 1018-1025. doi:10.1016/j.wasman.2008.08.018

[21] J. Gomes, J. Nascimento and H. Rodrigues, "Estimating Local GHG Emission-A Case Study on a Portugese Municipality,” Greenhouse Gas Control, Vol. 2, No. 1, 2008, pp. 130-135. doi:10.1016/S1750-5836(07)00098-9

[22] G. De. Gioannnis, A. Muntoni, G. Cappi, and S. Milia, "Landfill Gas Generation after Mechanical Biological Treatment of MSW: Estimation of Gas Generation Rate Constants,” Waste Management, Vol. 29, No. 3, 2009, pp. 1026-1034. doi:10.1016/j.wasman.2008.08.016

[23] A. V. Shekdar, "A Strategy for the Development of Landfill Gas Technology in India,” Waste Management and Research, Vol. 15, No. 3, 1997, pp. 256-266.

[24] A. D. Bhide, "Methane Emission from Landfills,” In: D. C. Parashar, C. Sharma and A. P. Mitra, Eds., Global Environmental Chemistry, Narosa Publication House, New Delhi, 1998, pp. 116-127.

[25] CPCB-NEERI (2004-2005), Survey on Million Plus Cities in India.

[26] H. Zhang, P He and Shao L, "Methane Emission from MSW Landfill with Sandy Soil Covers under Leachate Recirculation and Subsurface Irrigation," Atmospheric Environment, Vol. 42, No. 22, 2008, pp. 5579-5588. doi:10.1016/j.atmosenv.2008.03.010

[27] M. Rawat, U. K. Singh, A. K. Mishra and V. Subramanian, "Methane Emission from Landfill Areas of India", Environmental Monitoring and Assessment, Vol. 137, No. 1-3, 2008, pp. 67-74. doi:10.1007/s10661-007-9729-8

[28] K. R. Gurijala and J. M. Suflita, "Environmental Factors Influencing Methanogenesis from Refuse in Landfill Samples”, Environmental Science and Technology, Vol. 27, No. 6, 1993, pp. 1176-1181. doi:10.1021/es00043a018

[29] S. Kumar, A. N. Mondal, S. A. Gaikwad, S. Devotta and R. N. Singh, "Qualitative Assessment of Methane Emission Inventory from Municipal Solid Waste Disposal Sites: A Case Study,” Atmospheric Environment, Vol. 38, No. 29, 2004, pp. 4921-4929. doi:10.1016/j.atmosenv.2004.05.052

[30] J. A. Ladapo and M. A. Bariaz, "Isolation and Characterization of Refuse Methanogens," Applied Microbiology, Vol. 82, No. 6, 1997, pp. 751-758. doi:10.1046/j.1365-2672.1997.00154.x

[31] A. Garg, S. Bhattacharya, P. R. Shukla and V. K. Dadhwal, "Regional and Sectoral Assessment of Greenhouse Gas Emissions in India,” Atmospheric Environment, Vol. 35, No. 15, 2001, pp. 2679-2695. 


\section{doi:10.1016/S1352-2310(00)00414-3}

[32] IPCC, "Revised IPCC Guidelines for National Greenhouse Gas Inventories. Reference Manual,” Vol. 3. Inter Governmental Panel on Climate Change, Bracknell, 1996.

[33] S. Bhattacharya and A. P. Mitra, “A Scientific Analysis of Greenhouse Gas Emission Trends in India," Centre for Global Change, National Physical Laboratory, New Delhi, 2004.

[34] S. Mor, K. Ravindra, A. De. Visscher, R. P. Dahiya and A. Chandra, "Municipal Solid Waste Characterization and Its Assessment for Potential Methane Generation: A Case Study”, The Science of Total Environment, Vol. 371, No. 1-3, 2006, pp. 1-10. doi:10.1016/j.scitotenv.2006.04.014

[35] S. Sharma, S. Bhattacharya and A. Garg, "Greenhouse Gas Emission from India: A Prospective,” Current Science, Vol. 90, No. 3, 2006, pp. 326-332.

[36] V. Talyan, R. P. Dahiya, S. Anand and Sreekrishnan, "Quantification of Methane Emission from Municipal Solid Waste Disposal in Delhi," Resource Conservation and Recycling, Vol. 50, No. 3, 2007, pp. 240-259. doi:10.1016/j.resconrec.2006.06.002

[37] S. Gupta, N. Choudhary and B. J. Alappat, "Bioreactor landfill for MSW Disposal in Delhi," Proceeding of the International Conference on Sustainable Solid Waste Management, Chennai, 2007, pp. 474-481.
[38] A. Verma, V. Subramanian and R. Ramesh, "Methane Emission from Tropical Wetland," Current Science, Vol. 76, No. 7, 1999, pp. 1020-1022.

[39] A. K. Jha, C. Sharma, N. Singh, R. Ramesh, R. Purveja and P. K. Gupta, "Greenhouse Gas Emission from $\mathrm{Mu}$ nicipal Solid Waste Management in Indian Mega-Cities: A Case Study of Chennai Landfill Sites," Chemosphere, Vol. 71, No. 4, 2008, pp. 750-758. doi:10.1016/j.chemosphere.2007.10.024

[40] A. B. Ankolkar, M. K. Choudhury and P. K. Selvi, “Assessment of Methane Emission from Municipal Solid Wastes Disposal Sites," Current Science, Vol. 12, No. 4, 2008, pp. 49-55.

[41] I.-C. Chen, U. Hegde, C-H. Chang and S. S. Yang, "Methane and Carbon Dioxide Emissions from Closed Landfill in Taiwan,” Chemosphere, Vol. 70, No. 8, 2008, pp.1484-1491. doi:10.1016/j.chemosphere.2007.08.024

[42] J. Bogner and E. Matthews, "Global Methane Emission from Landfills: New Methodology and Annual Estimates 1980-1996,” Global Biogeochemical Cycle, Vol. 17, No. 2, 2003, pp. 1065-1082. doi:10.1029/2002GB001913

[43] J. T. Houghton, B. A. Callander and S. K. Varney, "Climate Change: The Supplementary Report to the IPCC Scientific Assessment," University Press, Cambridge, 1992, p. 200. 